\title{
Self Estrangement in Samuel Beckett's Existentialism and Theatre
}

\author{
Saeid Rahimipoor \\ English Dept, Ilam Edu. Org, Modarress TTC, Iran \\ Email: sdrahimipour@Yahoo.com
}

\begin{abstract}
Samuel Beckett, an outstanding $20^{\text {th }}$ century literary figure, has contributed a lot to solving the existential problems of man through a large number of oeuvre. Being familiar with all philosophical schools of thought and especially a proponent of existential philosophical movement, he was well aware of this school of thought characteristics and its underlying themes, such as anxiety, horror, liberty, the harbinger of death and finally consciousness of existing, a perspective on life that is a quest for the meaning of life and existence. In this search, however, he advocates Kierkegaard and the idea that human beings can be understood only from the inside that is, based on their lived and experienced reality and dilemmas not from the outside employing different branches of science. On this line, via the Theatre of Absurd, he tries to demonstrate man's attempt in his query for his estranged self.
\end{abstract}

Index Terms-Beckett, self estrangement, existentialism

\section{INTRODUCTION}

Twentieth century has been the age of the outbreak of two world wars resulting in the spiritual disillusion. This alongside the relativity theory of Einstein, the Darwinist theory of the survival of the fittest, existentialism philosophy principles, and many more changes to be discussed later on greatly influenced literature in the western world. These obsessions are well manifested in $20^{\text {th }}$ century writers of prose fiction including Franza Kafka whose novels and stories' characters also face alarmingly incomprehensible predicaments which have highlighted this modern sense of human purposelessness in a universe without meaning or value as the absurd nature of human existence, and philosophers like Sartre and Shariatti ${ }^{1}$ who has stipulated the point as follows: From the ancient times to the renaissance and even to $17^{\text {th }}$ and $18^{\text {th }}$ century, Human being has had the same clear -cut definition as other natural phenomena have had. Human being as a creature on the globe has had a taken- for- granted meaning. But with the advent of $20^{\text {th }}$ century and its idiosyncrasies, the already taken-for-granted defined creature turns to the most passive of all, bewildered, disillusioned, dislocated and purposeless. Philosophers, Intellectuals and even ordinary people all encounter the bewilderment of simple questions: Who am I? What am I? Why am I here? What will be the be-all and the be-end of me?

\section{DISCUSSION}

This attitude is also reflected in the works of the dramatists of the 1950 including Edward Albee, Vaclav Havel, Jean Genet, and Ionesco just to name some. On the line of handling these ambiguities, drama again has proved to be promising. Metman, asserts that, by far the most profound and daring writer associated with this development in drama reflecting the man condition in twentieth century has been Samuel Beckett, who has gone considerably further than any of his contemporaries. Instead of merely showing human existence in its unadorned nakedness, he strips his figures so thoroughly of all those qualities in which the audience might recognize itself that, to start with, an alienation effect is created that leaves the audience mystified. That is to say, the vacuum between what is shown on the stage and the on looker has become so unbearable that the latter has no alternative but either to reject and turn away or to be drawn into the enigma of plays in which nothing reminds him of any of his purposes in and reactions to the world around him. Samuel Beckett has been influenced by the French existential philosophy of Sartre and Camus that held human beings simply exist in a universe. Beckett read various philosophical treaties; he dealt specifically with Descartes, Schopenhauer, and Geulincx. They were the major sources of influence on Beckett's view of the world and his literary writings. They mainly formed his framework of existential thinking. The world in which Beckett begins to write is one without unity, clarity, rationality, or hope, and where man feels himself alone and a stranger in a place which itself will one day cease to exist. "From this confrontation between the unreasonable silence of the universe and the human need to be, there arises that futile revolt against existence; the painful rebellion of the spirit against three necessities - the object necessity of begin born , the hard necessity of living, and the sharp necessity of dying -which is constant through Beckett's works" ${ }^{2}$. Existentialism which is a movement in twentieth-century philosophy and literature centers on the individual and his or her relationship to the universe or God. It focused on the person, on individual existence, subjectivity, and choice. Two main existential doctrines assert that there is no fixed human essence structuring our lives 
and that our choices are never determined by anything except our free will. The origin dates to Plato's famous idea, "Essence precedes existence." This idea, introduced by Aristotle, thousands of years ago gave rise to a number of different models for looking at life, and of course it still does. It states that existence doesn't just happen, that some essence (or meaning? or purpose? or creator?) must come first, and that out of this essence comes our existence. The Essential Man exists, in other words, before any individual person existed, and all people are derived from this perfect essence. Our existences therefore have meaning to the extent that we are able to understand or sense this larger essence. We use our existence in this Platonic view to understand the essence, to recognize it, to conform and maybe even submit to it. What is the comfort, and what is the cruelty of this view? The comfort is that as humans made from the same blueprint; so to speak, we can all understand and generally feel the same things. The cruelty of this Platonic view is that we will never be able to feel (or even think?) anything that each generation before us hasn't already felt. Even during those times when our feelings are so strong that we naturally assume no one else ever could have experienced or felt such fine or rare emotions, people still have. The fact that our existences all come from the same essence guarantees it. Existentialism reverses the emphases of Plato's observation. It theorizes that "Existence precedes essence." There is no universal or divine blueprint or creating essence, this view maintains. Existence simply happens on its own, and we devote time and energy to looking at the nature of our existence in order to try to generate from it a useful meaning or essence. It correlates with the tabula rasa concept of John Lock in that upon that existence one assigns an existence. One person can conclude that life or existence means one thing and another can conclude differently. Or the same person can decide different things at different times about the meaning of his existence. The slipperiness and difficulty of the nature of the existence makes this possible, maybe even likely. The comfort and the cruelty of this view can be seen in Jean-Paul Sartre's phrase "Man is condemned to be free" ${ }^{3}$. We have no predefined or archetypal pattern to guide us and this certainly represents a freedom, but it is probably more freedom than most would desire. This desire, on the one hand, goes as far as that they treat religion, science, or other external factors as constraints and limits on the way of their individual freedom. On the other hand, it creates an opportunity for evading the responsibility for their own deeds and behavior by simply declaring that they are driven by factors beyond their control and that what they do can not be. This is where exactly the crisis of human identity, his ambiguity of self arises. This school of philosophy forms the building block of the theater of absurd which is the dominant form of drama at $20^{\text {th }}$-century. This theatre departs from realistic characters, situations, already accepted traditions, and finally a theatre in which time, place, and identity are ambiguous and fluid. The movement flourished in the mid-20 century Europe. Nineteenth-century precursors to this school of thought include some notable $19{ }^{\text {th }}$ century precursors include Kierkegaard and Nietsche. Other20 -century notables include Albert Camus, Jean Genet, Andre Gide, Simone de Beauvoir, Franz Kafka, and Beckett. One of the most basic philosophical questions asked is whether there is any meaning in our existence at all. The human necessity of unifying explanation of world has always been satisfied by religion and creators of the philosophical systems who made the human life meaningful. The natural desire to get to know and understand the world in its most hidden spheres was fulfilled by religious dogmas about the existence of God, which guaranteed the meaningful contingency of human life. From the time of Zarathustra, the old everyday certainties of life started to loose their certainty. World War I and World War II caused deep destruction and loss of human ultimate certainties and definitely brought about a world missing any unifying principle, a world senseless and disconnected with human life. If one realizes the absence of sense, and this is the expression of the spirit of epoch, in which the Theatre of the Absurd is rooted, the world becomes irrational and the conflict between the world and the human being who begins to be estranged from it arises here. Literature has got to mirror this view of modern human being.

Ever since, the first passionate warnings of Kierkegaard and Nietzche about a hundred years ago; a small minority in the field of art, Literature, and philosophy have been accompanied by an increasing feeling of urgency about man's selfestrangement in the modern world. Additionally, this reaction has not started with drama. The idea of man's tragic selfestrangement or I call it self ambiguity has been expressed in the works of, for example, Dostoyevsky, Rilke, and Kafka, Beckett and those writers of very varied orientations who have - against their protest - been thrown together under the common description of "existentialists" ${ }^{4}$, including

Heidegger, Jaspers, and Sartre. All that these have had in mind to do has been to help man in his collective existence and from the tragic absurdity of his self estrangement by enabling him to face the agony and problems of life, and his self obsessions. Many intellectuals have tried to present a justification like lack of meaning in modern life and the vacuum by which man's religious instinct has been starved or cut off, but to philosophers and dramatists who have shown themselves acutely aware of modern man's self - estrangement assert that it cannot be overcome unless pathological psychic developments are allowed to contribute to the problem solving of man's crisis of his self. Self definition and self realization at the mercy of alterations of the time, requires appropriate attention and modification. The scope of the self is not limited to Philosophical view as Sartre defines consciousness as "a being, the nature of which is to be conscious of the nothingness of its being"5 nor to the sheer psychological one for both are out side of the

\footnotetext{
3 Quoted in Kaufmann, W (1957). Existentialism from Dostoyevsky to Sartre , London, p.142

4 Kaufmann, W (1957). Existentialism from Dostoyevsky to Sartre, London, p.142

5 Sartre, J.P. (1956), “Bad Faith” Jean - pawl Sartre: Essays in Existentialism. Ed. W. Baskin. New Jersey: Carol publishing Group, - 147,148.
} 
framework of the research. Instead the view of the self which forms the essence of identity will be taken into account and surveyed from Beckett's theatre view point.

Beckett's reticence in shedding light on his philosophical concepts can not be interpreted as mere whim from critics' view point. Indeed, it might be argued that in correlation between the authors and the critics' attitude lays one of the keys to the whole phenomenon of Beckett, his oeuvre, and its impact. Some critics conclude that Becket does not concern himself with abstract and general verities, even if there were room for them in his view of the world. But to Esslin "paradoxically, however, Beckett's refusal to be more than a painstaking recorder of his modes of existence, his categorical refusal to allow any philosophical meaning or thesis is to be attributed to his work, is precisely the aspect of his activity that lifts his precarious and perilous enterprise into a sphere of significance beyond the scope of most other artists" 6 . To come to understanding of one' self and its revelation in one's oeuvre, no doubt, is not an easy task. It requires Attention and consideration knowing the fact that this attention has been shattered, which can not be the source of the consciousness upon which one can realize his own sense of self, and finally upon that felt self assign his own self an identity. This is in a sense because the world "is no longer turned toward the origin, affirms play and tries to pass beyond man and humanism, the name of man being the name of that being who, throughout the entire history of metaphysics of onto-theology; in other words, throughout his entire history-has dreamed of full presence, the reassuring of foundation, the origin and the end of the play" ${ }^{7}$. This view is what exactly Becket reveals in an idiosyncratic way in his plays. The concept of self was theorized by Descartes, Rousseau, Hegel, and countless other western philosophers. This self can be determined or known differently. For some only through self presence one can get rid of the miseries of the world. To some, there is a need "to structure experience and fix the poles of self and world". To these people, "the real Fall occurred not in Eden but in our century. After the accumulation of too much history, we have lost the innocence required to believe in any more explanations. The only certainties left are the falseness of all interpretative structures and the radical unintelligibility of human experience without them" ${ }^{8}$. Descartes asserts that one can come to an idea of the self only through contemplation. On the other hand, Deleuze and Deman claim that Self can not be contemplated by itself: "We must always contemplate something else in order to be filled with an image of ourselves" ${ }^{9}$.

This flash back to the concept of self in philosophers' view point, paves the way for the way the concept is treated in Beckett's works. Beckett, with this regard, rather than attempting to define or give shape to his own life - to make himself present to himself through writing his works explores the notion of the self. From his work, we come up with the idea that the self is able to produce the text, but it is in turn subject to being produced by text, even more, in the end, reduced to nothing more than the text itself. As a to the point reference to the idea of the way self is projected and revealed a comparison proves promising. From philosophical view point, Descartes ultimately is able to give form to the subject through self-reflection and production of footfalls. Whether they are, what they are "not quite there" is the status which the majority of Beckett's characters suffer. Some characters like Ada in Embers is not "present" at all, because they are not at all alive. Some others are ghost- Beckett's characters never get to that stability. They are rarely present at present. For example, one of Beckett's favorite actresses, Billy Whitelaw, became cunningly cognizant of the ambiguous states of being in Beckett's work while preparing for a like, not entirely absent, but not present either. One point which strikes readers' mind with regard to the ambiguity of self in Beckett's works is the fact that Beckett's characters, especially in his novels, do not seem human and even though they are endowed with a name and human physical form, their identities do not remain stable long. For example, in Waiting for Godot, he introduces the hazardous zones in the life of the individual, perilous, precarious, mysterious and fertile, when for a moment; in the individual's life the suffering of being replaces the boredom of living which is opposite to the obsession of his contemporary playwrights. For example, the anguish Pinter's characters experience has more social, psychological, and mental basis originating from their failure in having stability of identity, feeling self esteem and respect within them. Some outside and in case of many of his character's an inside sense of disillusion or threat blur their view of their selves and identities. This blockage of one's view of life and identity may have originated from the absurd philosophy of life, existence, and one's sense of self. Krapp in Krapp's Last Tape is handling his fragmented selves. This can be due to the fact that "we can be multiple people simultaneously, with no one of these selves necessarily more valid than any other" ${ }^{10}$.This touches upon one's senses in revealing the instability of self or its ambiguity which gives rise to all problems of life, existence, and death that modern man is facing in this world. In Waiting for Godot, the characters sound like vagrants, invisible like Godo, slippery and submissive like Pozzo and the like. In Engame, the father and mother figures suffer from the lack of self stability and respect. Even son figure, Hamm, and Clov, from another view point, both suffer the same view of individual's self. Each character proving to be a paragon of modern man well reveals this aspect of modern man's obsessions. To dissolve them, man has to surpass the arduous blurring obstacles which have hindered his understanding of his self, identity, existence and philosophy of his being. In this contemporary period, people do not have any ideals before them to whom they can surrender their life and go on living with relax certainty. They are

6 Esslin, Martin (2004). The Theatre of the Absurd. New York: Vintage Books, p, 61

7 Derrida, Jacques (1978). Writing and Difference. Alan Bassr Tran. Chicago: Chicago University Press.1978, p.292

8 Levy, Eric (1980). Beckett and the Voice of Species: A Study of the Prose Fiction. New York: Barnes and Noble, p.10

9 Deleuze .Quoted from the first published text of the English version in Ever Green Review No. 30, Faber and Faber, London p. 74-75

10 Baym, Nancy K. (2000). The emergence of on-line community. In Cyber society 2.0: Revisiting computer-mediated communication and community, ed. Steven G. Jones, 35-68. 
rejection of those ideas, of economic and ideological governmental violence, which disregard who we are individually. They are also a rejection of a scientific or administrative questioning which establishes one's identity"11. We can not imitate anybody's ideals which can be either too high or too below of the capacity of human beings. So man should try to identify his or her capacities and go on living after scrutinizing the different philosophical contradictions and coping with the dominance of absurdity in his life.

\section{CONCLUSION}

Unlike philosophical debates hanging in abstractness, Beckett crystallizes the manifestations of existentialism philosophy in his oeuvre through his idiosyncratic theater and his specifically created characters to deal with one of the great obsessions of modern man that is his estranged, dislocated, and dispossessed self. He has introduced this through successions of characters of one single character or pseudo-couple characters, or turning the characters to their sheer blurred invisible voices. He has dealt with, introduced, and manifested one of the abstract existential obsession of modern man regarding his self and philosophy of existence that no one has ever been that much assertive and promising in its revelation. The main reason for the displacement and estrangement of self, no doubt, in his theatre originates from the absurdity which has dominated man at the post modern era which Beckett has crystallized it in his existential philosophy via his idiosyncratic theatre of Absurd. The sheer gist of this absurdity can be inferred from Eliot's Sweeny Agonistes: Birth, and copulation, and death. That's all, That's all, That's all. Birth, and copulation, and death. The only way to get rid of this state of self fluidity that Beckett has wished to illustrate in his plays is through the sheer awareness of the audience to come to their own understanding of their own perceived and stabilized sense of their selves.

\section{REFERENCES}

[1] Afroghe, Shahram. (2010). Post modernism, Theatre, Beckett, Boroujerd: Azad U. Press.

[2] Artaud, A. (1958). The Theater and its Double Transe. Mary Caroline Richards. New York: Grove Press.

[3] Baym, Nancy K. (2000). The emergence of on-line community. In Cyber society 2.0: Revisiting computer-mediated communication and community, ed. Steven G. Jones. London: Sage Castells 35-68.

[4] Beckett, Samuel (1931). Proust. London: Chatto and Windus.

[5] Berlo, D. (2000). The Process of communication. New York: Elatoteno.

[6] Camus, Albert. (1955). The Myth of Sisphus and Other Essays, New York: Vintage.

[7] Derrida, Jacques. (1978). Writing and Difference. Chicago: Chicago University Press.

[8] Esslin. M. (1969). Reflection: Essays on Modern Theater. New York: Doubleday and Company.

[9] Esslin. M. (2004). The Theatre of the Absurd. $3^{\text {rd }}$ ed. New York: Vintage Books.

[10] Kaufmann, Walter. (1957). Existentialism from Dostoyevsky to Sartre. New York: Meridian Books, Inc.

[11] Lall, Ramji. (2001). Waiting for Godot. New Delhi: Rama Brothers Publication.

[12] Lawrence E. Harwey. (1967). "Art and the Existential in Waiting for Godot", in Ruby Cohn (ed), Casebook on Waiting for Godot. New York: Grove Press Inc., 144-155.

[13] Levy, Eric P. (1980). Beckett and the Voice of Species: A Study of the Prose Fiction. New York: Barnes and Noble.

[14] Metman, P. (1955). The Ego in Schizophrenia: Part I. The Accessibility of Schizophrenics to Analytical Approaches. Journal of Analytical Psychology, Vol. 1,161-176.

[15] Nietzsche, F. (1955). Also Sprach Zarathustra, Vol. II, Munich: Hanser.

[16] Sartre, J. P. (1956). Bad Faith: Essays in Existentialism. Ed. W. Baskin. New Jersey: Carol publishing Group, 147-148.

[17] Shariati, Ali (2008). The Alienated Man. Tehran: Ghalam Publication.

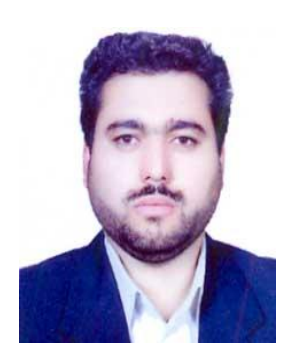

Saeid Rahimipoor was born in 30/08/1973 in Shirvan Chardavol, Ilam, Iran. He completed B.A. in Shiraz University in Iran on "English Literature" in 1998. In 2000, he successfully completed M.A. in Tarbiat Modarress University in Iran on "TEFL". In 2011, he received Ph.D. In Yerevan state University on the Specialty of "English Literature" in Armenia.

His areas of interest include literature, drama, methodology, and interdisciplinary researches. He has been a Lecturer offering courses of different types from ESP to specialized courses on novel, English literature, and drama in different universities in Iran. He has been Manager of Iranian Language Institute in Kuwait for two years. He has been Scientific Referee in International research conference in Armenia. He is currently Head of English department in Ilam Moddarres TTC and Manager of Navid Language Institute. He has published many articles including: -Beckett's Pseudo-couples: Reflection of the Ambiguity of Self. The Context Yerevan State University Journal. 2010 No 21, Pp.87-98 -The Quest for Self in Beckett's Drama. Cultural Perspectives-Journal for Literary and British Cultural Studies In Romania. No.15, 2010, Pp.183-192 - The Search for Self and Identity in Harold Pinter's Plays. Bovah Yerevan Ministry of Higher Education Journal. 2011Vol.2, No. 47, Pp.27-33

Dr. Rahimipoor has been elected as the best researcher twice in Iran Education Organization English Secretariat and in Iranian First Teacher Research Conference in Kuwait. 